ISSN 1991- 8690

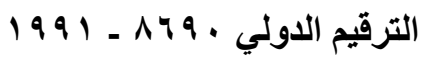

website :http:// jsci.utq.edu.iq

Email: utjsci@utq.edu.iq

\title{
Comparision between coelomocyte cells isolated from coelomic cavity of earth worm and leucocytes
}

\author{
Saba T. Mohammad* Ekhlass N. Ali* Majida G. Magtooph ** \\ *Department of Biology- College of Science- Al-Mustansiryiah University \\ ** Department of Biology- College of Science- Thi - Qar University
}

\section{$\underline{\text { Abstract }}$}

The coelomocytes of Lumbricus terrestris have been isolated \&described by used simple \&modified method, ,the viability of isolated cells were (85\%), and to diffrentiate the type of cells, stained by Leishmans stain, have been observed the more type cells which (granulocyte\&neutrophile). All cell types, produce pseudopodia and are capable of phagocytosis. The phagocytotic activity of the coelomocytes to engulf. Killed yeast cells (Saccharomyces cerevisiae) assessed in vitro and compared with phagocytic cells(polymorphic nuclear cell) isolated from human, was found the phagocytosis process increase with time the capacity of human phagocyte to excel in phagocytosis compared with coelomocyte was $(86.1 \%, 67.1 \%)$ respectively.

Key words: Lumbricus terrestris, phagocytosis

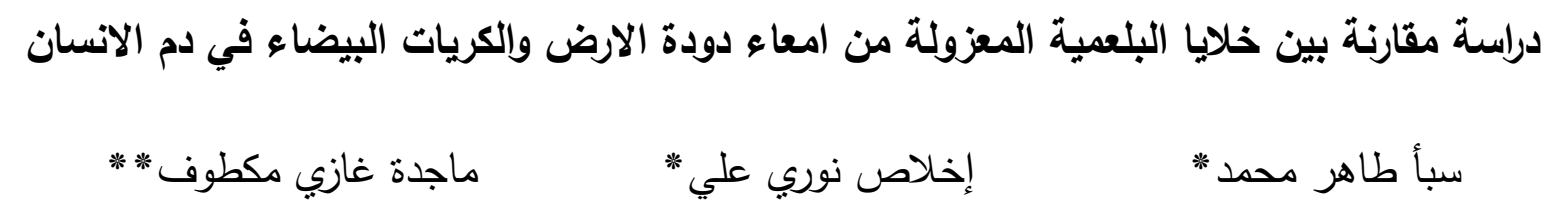

(ekhlassnoori@yahoo.com) (shebajanaba@yahoo.com) قسم علوم الحياة - كلية العلوم- الجامعة المستتصرية" * ق قسم علوم الحياة - كلية العلوم- جامعة ذي قارم

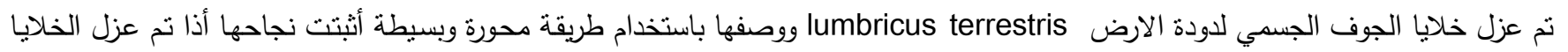
بنسبة حيوية كانت (1)\%) ولمعرفة أنواع الخلايا تم تصبيغها بصبغة لثمن أذ لوحظ بان اكثر انواع الخلايا كانت هي (granulocyte\&neutrophile) كانت معظم الخلايا المعزولة لها القدرة على تكوين أقدام كاذبة ولها القدرة على البلعمة. تم أختبار قابلية الخلايا الجوفية على بلعمة خلئ خلايا الخميرة المقتولة.

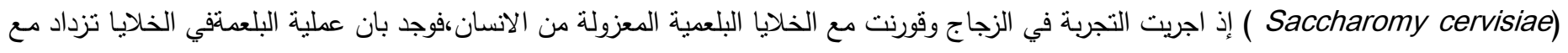
الزمن وان خلايا البلعمية للانسان كانت لها القدرة على البلعمةأفضل من الخلايا الجوفية لدودة الارض أذ بلغت النسبة المئوية للبلعمـة(86.1\% 67.1\% على التوالي.

\section{$\underline{\text { Introduction }}$}

Coelomocytes are considered the immune cells of lower coelomate annelida, mollusca, arthropoda).These cells are types of leukocytes that have long been considered to constitute the major innate (unspecific) immune defense system of these animals (Hostertter 
and cooper, 1972) (Engelmann et al.,2004 ).The coelomocytes of annelids vary widely in morphology, not only between classes but also between species of the same family (Stein and cooper , 1983). The coelomocytes are generally divided in two main groups by light microscope: amoebocytes (phagocytes) and eleocytes (chloragogen cells), which are not phagocytic (Ratcliffe and Rowley, 1981). Eleocytes which can be found in almost all annelids are generally big cells and have granules (chloragosome) that contain lipid, lipid like and protein substances, although such cells have no phagocytic features (Tripp,1992).Ameobocytic coelomocytes are extremely efficient removing foreign particles,such as bacteria,fungi and nemtodes from the coelmic cavity by either phagocytosis, nodule formation or encapsulation.( Millar and Ratcliffe , 1994), and can reach all tissues and all parts of the earthworm body( Cooper ,1986) ( Anna and Jan , 2001 ). Earthworms Lumbricus terrestris and Eisenia foetida phagocytes generally have four cell Types such as basophills,neutrophils,acidophils and granulocytes according to their morphological and cytochemical properties( Millar and Ratcliffe, 1994) (Linthicum et al ., 1977 ) (Stein and cooper , 1978 ) .Earthworms have both cellular and humeral defense mechanisms these cells types are studied Because they provide information about mechanism governing innate immunity in this worm.In this study we came to isolate macrophage from earthworm by use new and simple method, also to study its phagocytosis response to yeast compared with phagocytic cell isolated from human.

\section{Materials and Methods}

\section{Subjects:}

Earth worms derived from a single source in ALMustansyria university garden they were transferred and maintained in clean petri dish contain $15 \mathrm{ml}$ from phosphate buffer saline at $10 \mathrm{C}^{\circ}$ in the absence of light for 2 days. Buffer Solution exchange every day before experimentation for cleaning the coelom cavity of the worm from the soil and another particles.

\section{Methods:}

\section{Isolate of coelomocytes}

In the beginning to clarify that the method we have used in this research is modified method and we summarized it in the following point:-

1- The clean worms were placed into a glass Petri dish containing $6 \mathrm{ml}$ of $4 \mathrm{C}^{\circ}$ Hanks Balanced Salt Solution (HBSS), in average of three worms in each Petri dish.
2- One-fourth of the posterior part of the body was massaged. To expel the content of the lower gut and stimulated muscular contraction that resulted in extrusion of mucus that contained coelomocytes through body wall pore.

3- The cells were then transferred to a $15 \mathrm{ml}$ polypropylene tube containing $12 \mathrm{ml}$ of calcium-free HBSS.

4- The cells were washed twice with the same media.

5- Then petri dish contents were poured into centrifuge tube maintained in crushed ice.

6- Tubes were then centrifuged for 6-8 min at 150 $\mathrm{xg}$ at $4 \mathrm{C}^{\circ}$.

7- The supernatant decanted and coelomocytes resuspended in $6 \mathrm{ml}$ at $4 \mathrm{C}^{\circ} \mathrm{HBSS}$ supplemented with $0.35 \mathrm{~g} / \mathrm{L} \mathrm{NaHCo3}$.

8- Count and adjust to $1 \times 106$ coelomocytes $/ \mathrm{ml}$.

\section{Determination of Viability}

Coelomocytes viability were determined by the trypan blue exclusion method (Johnstone and Thorpe, 1982 ).Samples of $50 \mu 1$ of $0.4 \%$ solution of trypan blue. Then a drop of mixture was introduced in haemocytometer chamber of viable and dead cells was determined microscopically expressed as present live.

\section{Preparation of Yeast (Saccharomyces cerevisiae)}

1 -Suspend 1package yeast in approximately $150 \mathrm{ml}$ $0.85 \%$ sterile $\mathrm{NaCl}$ in $500 \mathrm{ml}$ flask

2-Place in a boiling water bath for 1 hour

3-Filter through double-thick sterile gauze.

4-Count and dilute to $(1 \times 106)$ yeast $/ \mathrm{ml}$ with $0.85 \% \mathrm{Nacl}$

5- Aliquot and store at -20C ${ }^{\circ}$. (Metcalf et al.,1986).

In vitro phagocytosis experiments

Phagocytosis was determined by counting the number of coelomocytes containing at least one phagocytized yeast, a volume of $3.0 \mathrm{ml}$ of each cell suspension was prepared at a concentration of $(1 \times 106)$ cell $/ \mathrm{ml}$ cells resuspended in $1 \mathrm{ml}$, of $10 \mathrm{C}^{\circ} \mathrm{HBSS}$.containing ( $1 \times 106$ )inactivated yeast cells. After the coelomocyte-yeast mixture was incubated at $37 \mathrm{C}^{\circ}$ for 30,60 minute.Undiluted replicate sample were made smear on the clean glass slide left to dry in air fix with methanol, stained with Leishmain stain for $2 \mathrm{~min}$.

The cells were counted under the light microscope and both phagocytic index (PI) and percentage of phagocytosis $(\% \mathrm{P})$ were calculated for every slide using equations below respectively (Cotuk and Kalac , 1990). Number of Phagocytic Cells

$\mathrm{PI}=\quad$ Total Number of Cells 


$$
\mathrm{P} \%=\frac{\text { Number of Phagocy tic Cells }}{\text { Total Number of Cells }} \times 100
$$

Preparation of polymorphicnuclears (PMNs) by dextran sedimentation

1- blood obtained from healthy volunteers.

2-10 $\mathrm{ml}$ whole heparinized peripheral blood is mixed with an equal volume of $3 \%$ dextran.

3-Cells are allowed to sedimented by gravity at room temperature for 20 minutes.

4-Neutrophil-rich supernatant is removed and centrifuged at $400 \mathrm{xg}$ for 10 minutes at $4 \mathrm{C}^{\circ}$.

5-The supernatant is discarded and $10 \mathrm{ml}$ of $0.2 \%$

$\mathrm{NaCl}$ is added to lyse the RBCs.

6-Centrifuge the lysed samples at $400 \mathrm{xg}$ for 10 minutes at $4 \mathrm{C}^{\circ}$ discard the supernatant and wash the cell pellet twice using cold HBSS and centrifuging at $400 \mathrm{xg}$ for 10 minute at $4 \mathrm{C}^{\circ}$.

7-Resuspend the washed cells in ml HBSS, counted, and adjusted to $1 \times 106 \mathrm{PMN} / \mathrm{ml}$ ( Harbeck and Gielas ,1991).

\section{Phagocytosis}

1-Add $0.250 \mathrm{ml}$ HBSS(cold), $0.250 \mathrm{ml}$ normal pooled sera (AB), 0.250 (PMN),,(cold)and

$0.250 \mathrm{ml}$ Saccharomyces cerevisiae.

2-The reaction tubes are incubated at $37 \mathrm{C}^{\circ}$ for 30 , and 60 minute period.

$3-0.1 \mathrm{ml}$ aliquots are removed from each reaction at 30 and 60 minute time point.

4-Made smear on the clean glass slide were stained with Leishmain stain for 2 minute.

5-The cells were counted under the light microscope and both phagocytic index (PI) and percentage of phagocytosis $(\% \mathrm{P})$ were calculated for every slide ( Metcalf et al ., 1986).

\section{Statistical Analysis:}

Data are presented as the mean \pm S.D.

\section{Results and discussion}

Our results of determinations of viability of coelomocytes was appeared $80 \%$. These results refer to the modified method which used to isolate the coelomocytes also( Toupin et al ., 1977) reported that the coelomocytes survived for at least 10 days with $85 \%$ viability as assessed by trpan blue exclusion assays and phagocytosis of heat killed yeast.The coelomocytes of L. terrestris cells have been distinguished, based on morphological properties as seen by light microscope with (leishman stain) .The phagocytosis likely to be neutrophils has nucleus and large cytoplasm containing vacuoles their cytoplasm containing fine strongly eosinophilic granules.(Fig 1). This results is similar to ( Suzuki and Cooper, 1995) (Kalac et al ., 2002 ) .By the early 1980 the cells had beencategorizedas follows.Type I Lymphocytic coelomocytes(basophils), Type II lymphocytic coelomocytes (basophils), TypeI granulocytes(neutrophils), TypeII coelomocytesgranulocytes, inclusion-containing coelomocytes(acidophils) (Vetrika and et al , 1994 ) ( Kasschau et al ., 2007 ). The coelomocytes can formed filopodia, or podial-like extensions these structure may enable the cells to better explore their environment ( Cotuk and Dales ,1984 a) .

\section{In vitro phagocytosis experiments}

Our results have shown that L. terrestris had a phagocytosis activity for saccharomyces used in the experiments(table.1,fig2).percentage of phagocytosis rate after 30 and 60 minute incubation was (\%62.5 and\% 67.16) respectively, while the percentage of phagocytosis in human was $(\%$ 82.5 and $86.1 \%$ )respectively .

Table - 1 Percentage of phagocytosis of L. terrestris compare in with percentage of phagocytosis in human

\begin{tabular}{|c|c|c|}
\hline \multirow{2}{*}{$\begin{array}{l}\text { Time of } \\
\text { exposure } \\
\text { (hr) }\end{array}$} & \multicolumn{2}{|c|}{ Phagocytic activity\% } \\
\hline & $\begin{array}{l}\text { Human } \\
\text { macrophage }\end{array}$ & Earthworm phagocyte \\
\hline $1 / 2$ & $82.5 \pm 0.7$ & $62.5 \pm 2.73$ \\
\hline 1 & $86.1 \pm 1.1$ & $67.16 \pm 10.5$ \\
\hline
\end{tabular}
against times.

Our results was against our exception that our theory the ceolomocytes are considered the immune cells of lower coelomate animals and considered the major innate (nonspecific) immune defense system of these animals therefore we assume the phagocytosis will be more active .The shortage of similar searches lead to made our discussion focused on characters and properties of this cells with the factors help to make the phagocytosis.

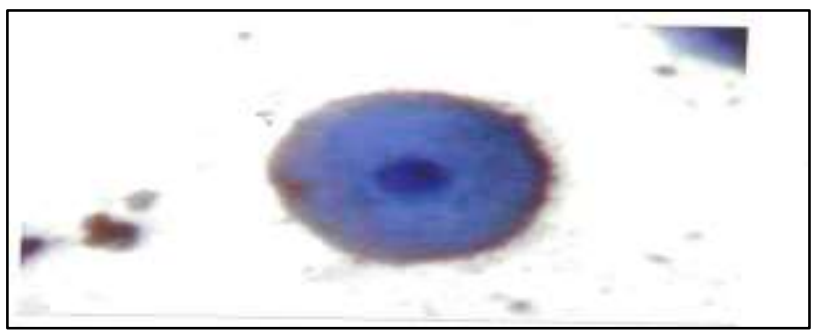

Fig (1) coelomocytes isolated from $L$. terrestris stained by leishman stain.40x 


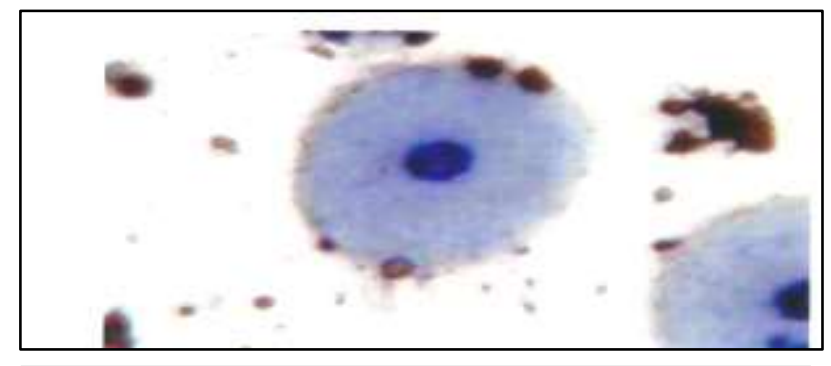

Fig (2) coelomocytes attach yeast after $1 / 2$ hours.40x

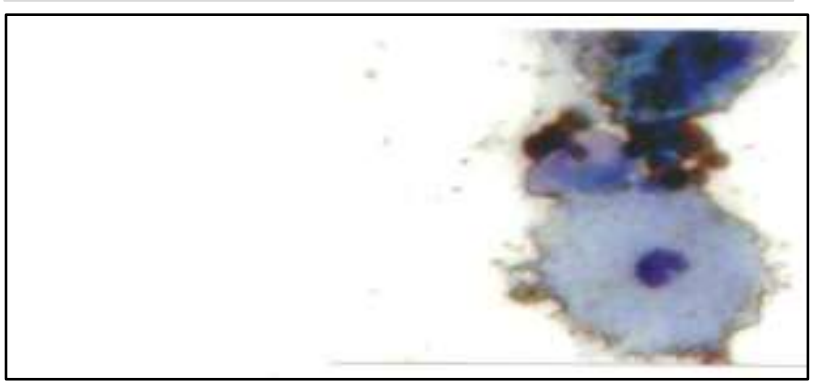

Fig (3) coelomocytes engulf yeast after 1 hours.40x

As we know that annelids have both cellular and humeral response to those infective agents, although earth worms have both cellular and humeral defense mechanisms some researchers have demonstrated that bacteria such as Aeromonas. Hydrophila, Bacillus megaterium ,Serratia marcescens (Anderson et al ., 1975 ), and Yersinia ruckeri ( Cotuk and Kalac , 1990) are phathogenic to some species of earth worms .The primary cellular response against invading microorganisms starts with recognition step and followed by ingestion and killing.Following. Contact of the foreign particles with phagocytic cell the next step is attachment recognition and attachment may be mediated, in part in a nonspecific way by physiochemical properties of foreign material such as surface change and hydrophotic. (Millar and Ratcliffe,1994) (Bilej et al., 1990) (Cossarizza et al ., 1996). Coelomocyte from various sources have been shown to be capable of phagocytosis and thus perform funtion of macrophages have natural killer cell features and show natural killer cell responses and mediate lytic reaction against several targets and also secrete antimicrobial peptide (Laulan et al.,1988). Earthworm coelomocytes have been shown to express protein with features of perform which is involved in cytotoxic activities (Linthcum et al ., 1977 ) ( Cotuk and Dales , 1984a ) shown that graft rejection in Lumbricus terrestris is mediated by granulocytic coelomocytes (neutrophils)(Kelly et al ., 1993) shown that L. terrestris leukocyte phagocytosis was enhanced by vertebrate $\operatorname{IgG}, \mathrm{C} 3 \mathrm{~b}$ complement fragments also similar receptors exist on earth worm leukocyte surface and the opsonization in vertebrates is related to presence of receptors on the surface of phagocyte membrane therefore the Lumbricus terrestris which partially share common structures and functions with components of vertebrate humoral immune reaction.

On the other hand humoral factors may faciliatate recognition and subsequent ingestion of foreign material by phagocytic cells. These factor which facilitate or enhance phagocytosis, are generally referred to opsonins (Kelly et al ., 1993) (Stein and Cooper, 1981). In vertebrate opsonins are mainly immunoglobulins and the third components of complement and specific recognition may also take place. .through carbohydrate-binding proteins called lectins. In invertebrate the body fluids and some tissues may have lectins and may act as recognition molecules so in the earthworm the coelomic fluid acts as an opsonin against. Some microbial agents (Stein and Cooper , 1981) (Kelly et al ., 1993) ( Cossarizza et al ., 1996) underlined the importance of time and temperature in phagocytosis of yeast by $L$. terrestris phagocytes. Based on our results showed there was significant difference was observed in the phagocytosis of killed yeast between coelomocytes, isolated from earthworm and polymorphic nuclear isolated from human also the coelomocyte can tolerance maintain in viability for long time. Stein and Cooper ,1978) shown that the enzymes acid phosphatase and betaglucuronidase are present in all types of coelomocytes, but are especially abundant in basophils and neutrophils, the differences in enzyme amounts correlate well with the differences in phagocytic activity of the various cell types.

\section{References}

1. Hostertter, R.K. and Cooper, E. (1972):Coelomocytes as effector cells in earth worm. Immunity. Immunol.com. 12 :155-183.

2. Engelmann,P.; Kiss ,J.; Cooper, E.L.; and Nemeth, P. (2004) Earthworm leukocytes kill Hela,HEP Earthworm leukocytes kill Hela,HEP-2,PC-12 and PA. 317 cells in vitro. Journal of Biochemical and Biophysical methods. 61 (1-2) :215-227

3. Stein, A. E.and Cooper, E. L.(1983): Inflammatory responses in annelids. Amer. Zool. 23: 145-156. 
4.Ratcliffe N.A. and Rowley, A. F.(1981): Invertabrate Blood Cells. 1. Academic Press.

5. Tripp ,M. R.(1992): Agglutinins in the hemolymph of the hard clam, mercenaria. J of Invertb Pathol. 59: 228-234.

6. Millar ,D. A, and Ratcliffe, N. A. (1994): Invertebrates In Immunology: A Comparative Approach. John Wiley \& Sons Publishers.

7. Cooper, E. L. (1986): Leukocyte activity during earthworm inflammatory reactions. Int J Reac. 3 175-184.

8. Anna, A. and Jan, W. (2001): Morphology and phagocytic activity of coelomocytes in .Dendrobaena veneta (Lumbricidaet) Zoologica.poloniae. 46 (1-4): 91-104.

9. L inthicum ,D.S. ; Stein, E. A. ; Marks, D. H. And Cooper, E. L. (1977): Electronmicroscopic observations of normal coelomocytes.from the earth worm, Lumbricus terresris Cell. Tiss. Res. 185: 315-330.

10. Stein, E.A. and Cooper, E. L. (1978) : Cytochemical observations of coelomocytes from the earthworm lumbricus terrestris. The histochemical journal .10 (6) : 657-678.

11. Johnstone, A. and Thorpe, R. (1982) : Isolation and fractionation of lymphocytes.in immunochemistry in practice. Blackwell scientific publication,oxford Pp:77-101..

12. Metcalf, M.T.; Gallin,J.I; Nauseef, W.M. and RootRichard,K. (1986): Laboratory Manual of Neutrophil function, Ravenpress, New York.pp 21-23.

13. Çotuk, A. and Kalaç, Y.(1990): Response of the earthworm Dendrobaena venetato bacterial infections. In: Microbiology in Poechilotherms. Lésél R. (Ed). Elsevier Press, Amsterdam.pp: 245-248.

14. Harbeck,R.J.and Giclas,P.C. (1991): Ingestion phagocytosis assay In Diagnostic Immunology Laboratory Manual. Ravenpress, New York. Pp.273-275.

15.Toupin, j.; Marks, D.H.; Cooper, E.L. and Lamoureux, G. (1977): Earth worm coelomocytes in vitro. 13 (4) :218-222.

16. Suzuki, M.M . and Cooper, E. L. (1995): Spontaneous cytotoxic earth worm leukocytes kill K562. Tumer cells. Zoological science. 12 (4) : 443-451.

17. Kalac.Y.; Kimiran, A.; and Cotuk, A. (2002) : The role of opsonin in phagocytosis by coelomocytes of the earthworm Dendrotaena .Veneta. J. of cell and molecular Biology 1: 7-14.

18. Vetricka,V.(1994): Immunology of Annelids. Bocaraton.FL: CRC press Inc,pp: 81-140, 151159.

29. Kasschau, M.R. ; Ngo, T.D. Sperter, L. M. And Tran, K.L. (2007): Formation of filopodia in earth worm (Lumbricus terresris) coelomocytes in response to osmotic stress.Zoology (Jena).110 (1): 66-76.

20.Çotuk, A. and Dales, R. P. (1984a) : The effect of the coelomic fluid of earthworm Eisenia foetida sav. on certain bacteria and the role of the coelomocytes in the internal defence. Comp Biochem Physiol. 78 (2): 271- 275.

21.Anderson, R. S.(1975): Phagocytosis by invertebrate cells in vitro: biochemical events and other characteristics compared with vertebrate phagocytic systems. In: Invertebrate Immunity. Maramorosch K. and Shope RE (Ed). Academic Press, New York, pp:153-180.

22.Bilej ,M.; Scheerlick, J. P.; Vanderiessche, T. De Baetselier, P.and Vetvica, V.(1990): The flow cytometric analysis of in vitro phagocytic activity of earthworm coelomocytes (Eisenia foetida, Annelida). Cell Biol International Reports. 14 (9): 832-837.

23. Cossarizza, A.; Cooper, E. L. ; Suzuki, M.M. ; Salvioli, S.; Cappri, M. and Franceschi, C. (1996): Earth worm leucocytes. That are not phagocytic and cross-react with several human epitopes. Can kill human tumor cell line. Exp. Cell .Res. 224 : 174-182.

24. Laulan, A.; Lestage,J. ; Bouc, A. M. and Chateaureynaud-Duprat. (1988): The phagocytic activity of Lumbricus terrestris leukocytes is enhanced by the vertebrate opsonins:IgG and complement C3b fragment. Dev.CompImmunol. 12:269-277.

25.Kelly, K. Cooper, E. L. and Raftos, D.A.(1993): A humoral opsonin from the solitary Urochordate Styela clava. Dev Comp Immunol. 17 (1): 29-40.

26. Stein, E. and Cooper, E. (1981):. The role of opsonins in phagocytosis by coelomocytes of the earthworms ,lumbricus terrestris Dev.Comp.Imm 